\title{
Ganglioneurocytoma of the spinal cord: report of a case and review of literature
}

\author{
Gianluca Marucci · Andrea Barbanera • \\ Elena Serchi · Alvaro Andreoli
}

Received: 9 March 2008/Revised: 27 July 2008 / Accepted: 12 September 2008 / Published online: 24 September 2008

(C) Springer-Verlag 2008

\begin{abstract}
A case of ganglioneurocytoma of the spinal cord in a 51-year-old man is reported. Patient presented with a progressively worsening back pain and hyposthenia of lower limbs. Magnetic resonance imaging of the spinal cord revealed an intradural lesion in the T10-11 spinal segments, hyperintense on T1-weighted sequences. Complete resection was achieved. The patient did not show evidence of recurrence 12 months after surgery. On histology, the lesion was composed of round to oval cells with fine granular, slightly eosinophilic to clear cytoplasm suggesting a neurocytic differentiation. Some ganglion cells were observed. Neither significant cytologic atypia nor mitoses were present. The neoplastic cells were strongly positive with synaptophysin and negative with glial fibrillary acid protein. Neurocytomas are uncommon tumors typically arising within the lateral ventricles near the foramen of Monro. Extraventricular neurocytomas have been reported at various sites with rare examples in spinal cord. In the present paper, a case of ganglioneurocytoma of the spinal cord is reported with review of literature and discussion of differences compared to neurocytomas of other sites.
\end{abstract}

\section{G. Marucci $(\square)$}

Section of Pathology, Department of Oncology,

University of Bologna, Bellaria Hospital,

Via Altura, 3, 40139 Bologna, Italy

e-mail: gianluca.marucci@ausl.bologna.it

A. Barbanera - E. Serchi - A. Andreoli

Section of Neurosurgery,

Department of Neuroscience,

Bellaria Hospital, Bologna, Italy
Keywords Neurocytoma - Ganglioneurocytoma · Spinal cord · Extraventricular neurocytoma . Neurocytic differentiation

\section{Introduction}

Neurocytomas are uncommon tumors typically arising within the lateral ventricles near the foramen of Monro. Extraventricular neurocytomas (EVNs) have been reported at various sites including cerebral hemispheres, thalamus, cerebellum, pons and rare examples in spinal cord [8]. Nevertheless, it has been reported that ganglion cell differentiation is present in $66 \%$ of cases of EVNs [2], to our knowledge in only two cases $[1,3]$ such differentiation has been observed in spinal cord.

\section{Clinical summary}

A 51-year-old man was referred for progressively worsening back pain. He presented hyposthenia of lower limbs. He underwent rehabilitative training without any improvement. He first performed lumbar neuroradiological workup (X-ray and MR) that did not show pathological alterations. In the following 6 weeks, a rapid worsening of symptoms was observed and, moreover, paresthesias of the left leg appeared. Neurological examination demonstrated: superficial hypoesthesia at T10 level; 4/5 hyposthenia of right leg; hyperreflexia of the flexor reflexes, and clonus of right foot; mild hypotrophy of muscles of lower limbs.

A whole spine MR imaging, performed 8 weeks after the previous examinations, evidenced an intradural lesion in the T10-11 spinal segments, and it was impossible to detect if the lesion was intramedullary or extramedullary 
due to its volume. After contrast administration, the lesion demonstrated intense contrast enhancement (Fig. 1). The lesion was associated with syringomyelia in T4-7 segments. Twenty days before hospitalization, the patient presented also sphincter dysfunction and gait imbalance. Before the operation the patient underwent a CT scan that did not demonstrate any intracranial lesion.

A T10-11 laminectomy and a microsurgical removal of the lesion were performed. After opening the dura, it was found to be a bluish-red lesion. Complete macroscopical resection was achieved.

The patient recovered well, neurological alterations disappeared and the weakness in the leg improved satisfactorily.

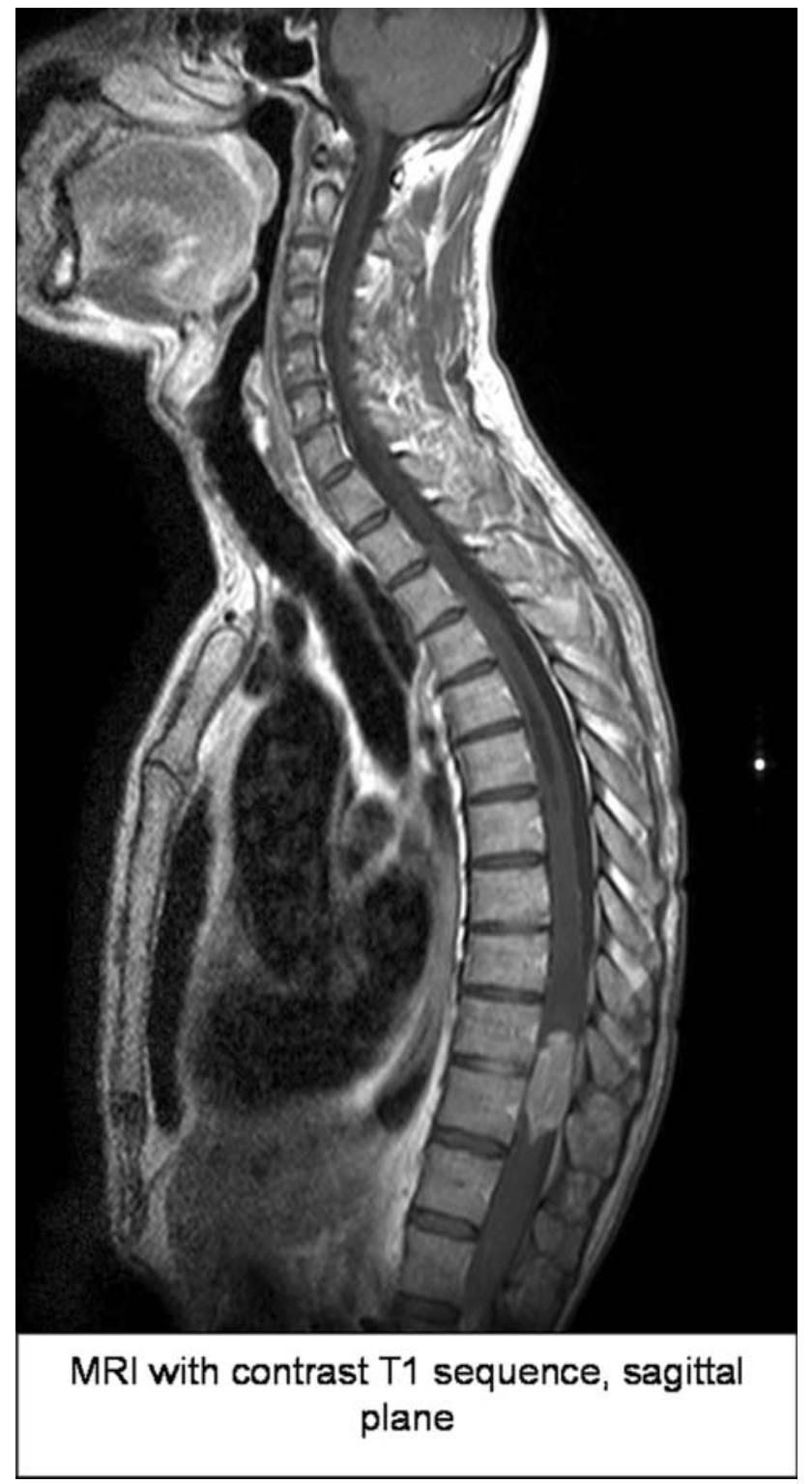

Fig. 1 MRI scan T1-weighted image with contrast injection showing enhancement of the lesion od sagittal plane
MR imaging at 3 months and 12 months post-operatively did not show either residual lesion or recurrence.

\section{Pathological findings}

Grossly, the resected specimen consisted of a solid, bluishred nodule measuring $2 \mathrm{~cm}$ in greatest axis. Tissue was fixed in $10 \%$ buffered formalin and embedded in paraffin. Two micron-thick sections were stained with hematoxylin and eosin. Subsequently, serial sections were cut from selected blocks and stained by a routine immunohistochemical method. On histology, the lesion was composed of round to oval cells with fine granular, slightly eosinophilic to clear cytoplasm. Neither significant cytologic atypia nor mitoses were observed. Necrosis was not present. The neoplastic cells were strongly immunopositive with antisynaptophysin antibody (Fig. 2) and negative with antiglial fibrillary acid protein antibody. Staining with antichromogranin antibody disclosed some ganglion cells interspersed among neurocytic tumor cells (Fig. 2). MIB-1 labelling index was $1 \%$ at the highest proliferative areas. A diagnosis of ganglioneurocytoma (grade I, WHO) was made.

\section{Discussion}

Neurocytoma is an uncommon tumor; exceptional cases have been reported in spinal cord [1, 3, 5, 7-12]. Spinal

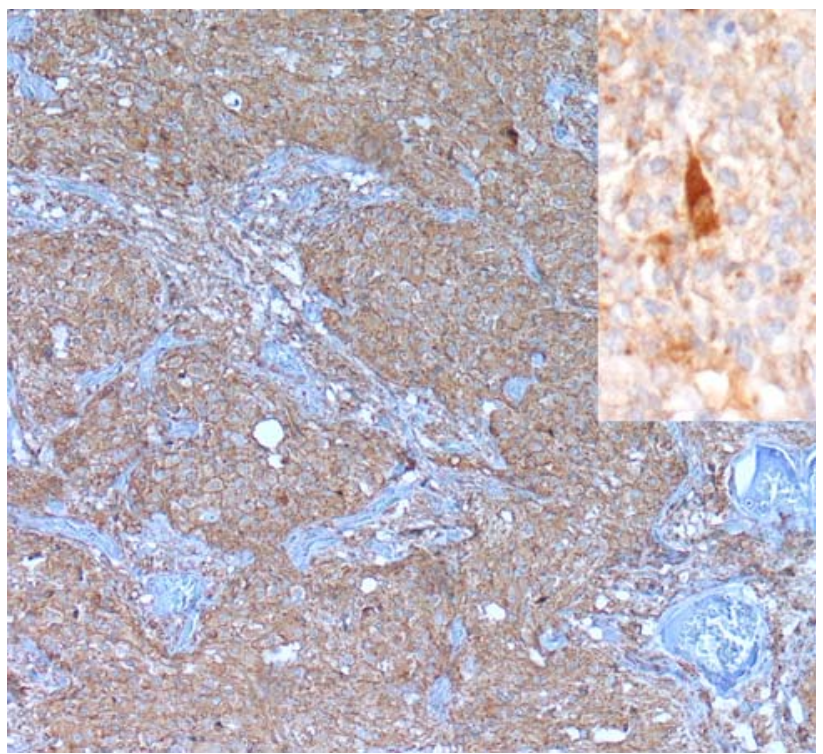

Fig. 2 Synaptophysin antibody is strongly positive in neoplastic cells. As demonstrated in the top right-hand corner, chromogranin antibody disclosed some ganglion cells interspersed among neurocytic tumor cells 
Table 1 Review of literature of spinal neurocytomas

\begin{tabular}{lllll}
\hline Case no. & Age/sex & Site & Histopathology & Follow-up \\
\hline $1[12]$ & 65/M & C2-6 & Typ. neurocytoma & NR \\
$2[12]$ & $49 / \mathrm{M}$ & C3-4 & Atyp. neurocytoma & R and DOD \\
$3[3]$ & $67 / \mathrm{M}$ & T10-11 & Typ. neurocytoma + G diff. & NR \\
$4[10]$ & $12 / \mathrm{M}$ & C4-T1 & Typ. neurocytoma & NR \\
$5[11]$ & $46 / \mathrm{F}$ & T12-L1 & Typ. neurocytoma & NR \\
$6[7]$ & $50 / \mathrm{M}$ & T2-5 & Typ. neurocytoma & NR \\
$7[8]$ & $24 / \mathrm{M}$ & C5-T1 & Atyp. neurocytoma & $\mathrm{R}$ \\
$8[1]$ & $13 / \mathrm{M}$ & T6-10 & Typ. neurocytoma + G diff & $\mathrm{NR}$ \\
$9[9]$ & $8 / \mathrm{M}$ & T2-T8 & Atyp. neurocytoma & NR \\
$10[5]$ & $49 / \mathrm{M}$ & C3-C5 & Typ. neurocytoma & NR \\
Present case & $51 / \mathrm{M}$ & T10-11 & Typ. neurocytoma + G diff & NR \\
\hline
\end{tabular}

$M$ male, $C$ cervical, $T$ thoracic, Typ. typical, Atyp. atypical, $G$ diff ganglion cell differentiation, $N R$ no recurrence, $R$ recurrence, $D O D$ death of disease
Conflict of interest statement None of the authors has any potential conflict of interest.

\section{References}

1. Baehring J, Ogle E, Sze G, Duncan C, Bannykh S (2005) Ganglioneurocytoma of the spinal cord. J Neurooncol 71:149. doi: 10.1007/s11060-004-5966-7

2. Brat DJ, Scheithauer BW, Eberhart CG, Burger PC (2001) Extraventricular neurocytomas. Pathologic features and clinical outcome. Am J Surg Pathol 25:1252-1260. doi:10.1097/ 00000478-200110000-00005

3. Coca S, Moreno M, Martos JA, Rodriguez J, Barcena A, Vaquero J (1994) Neurocytomas of spinal cord. Acta Neuropathol 87:537540. doi:10.1007/BF00294182

4. Figarella-Branger D, Söylemezoglu F, Kleihues P, Hassoun J (2000) Central neurocytoma. In: Kleihues P, Cavenee WK (eds) WHO classification of tumours of the nervous system. IARC Press, Lyon, pp 107-109

5. Gokhan GA, Gurer IE, Akyuz M, Tuncer R (2008) A case of extraventricular neurocytoma of the spinal cord. Neuropathology 28:322-325. doi:10.1111/j.1440-1789.2007.00843.x

6. Makuria AT, Henderson FC, Rushing EJ, Hartmann DP, Azumi N, Ozdemirli M (2007) Oligodendroglioma with neurocytic differentiation versus atypical extraventricular neurocytoma: a case report of unusual pathologic findings of a spinal cord tumor. J Neurooncol 82:199-205. doi:10.1007/s11060-006-9268-0

7. Martin AJ, Sharr MM, Teddy PJ, Gardner BP, Robinson SF (2002) Neurocytoma of thoracic spinal cord: case report. Acta Neurochir (Wien) 144:823-828. doi:10.1007/s00701-002-0980-z

8. Sharma S, Sarkar C, Gaikwad S, Suri A, Sharma MC (2005) Primary neurocytoma of the spinal cord: a case report and review of the literature. J Neurooncol 74:47-52. doi:10.1007/s11060004-3348-9

9. Singh A, Chand K, Singh H, Sarkar C, Sharma MC (2007) Atypical neurocytoma of the spinal cord in a young child. Childs Nerv Syst 23:207-211. doi:10.1007/s00381-006-0141-4

10. Stapleton SR, David KM, Harkness WF, Harding BN (1997) Central neurocytoma of cervical spinal cord. J Neurol Neurosurg Psychiatry 63:119

11. Stephan CL, Kepes JJ, Aronold P, Green KD, Chmberlin F (1999) Neurocytoma of the cauda equina: case report. J Neurosurg 90:247-251

12. Tatter SB, Borges LF, Louis DN (1995) Correction: central neurocytomas of cervical spinal cord. J Neurosurg 82:706 